\title{
A Comparative Description between New Record of Dragonfly Burmagomphus pyramidalis Laidlaw from Central India and Earlier Available Record
}

\section{Ashish D. Tiple ${ }^{1 *}$, Shyamkant S. Talmale ${ }^{2}$, Sonali V. Padwad ${ }^{3}$}

'Department of Zoology, Vidyabharti College, Seloo, Wardha442104, Maharashtra, India

${ }^{2}$ Zoological Survey of India, Central Zone Regional Centre, Jabalpur-482 002, Madhya Pradesh, India

${ }^{3}$ B1/8 Savitri Vihar, Somalwada, Wardha road, Nagpur -440025, Maharashtra, India.

Study Area: Jabalpur \& Hoshangabad District, Madhya Pradesh, India

Coordinates: N $25^{\circ}$ o8' 21.48” E $075^{\circ}$ o1' 52.52'

Key words: Pachmarhi Biosphere Reserve

\section{Abstract}

Burmagomphus pyramidalis Laidlaw, 1922 was reported so far from south to southwest India. Present report of the species from Tropical Forest Research Institute (TFRI) Jabalpur and Pachmarhi Biosphere Reserve (Hoshangabad Dist.), Madhya Pradesh is for the $\mathrm{f}$ irst time from the central parts of India. The study provides here variations in collected $B$. pyramidalis specimens in antehumeral marking on the thorax and the $9^{\text {th }}$ abdominal segment. In specimen two upper antehumeral portion narrow, broaden at middle, again somewhat narrow and broaden at extreme humeral portion touches to the base of $2^{\text {nd }}$ pair of legs, also interrupted at the middle at humeral region as against upper antehumeral portion broad, narrow at middle, and broaden at extreme humeral portion, however, a conspicuous transverse citron yellow band dorsally seen on hind margin. In specimen one 9 abdominal segment with two big yellow triangular marks dorsally present on hind margin. Variations between collected two specimens of $B$. pyramidalis and available description by Fraser (1926 \& 1934) are discussed.

Himachal Pradesh and Meghalaya. However, Wilson (2011) and Subramanian (2014) have not shown its distribution in India. Mishra (2007) studied the odonates of Madhya Pradesh and reported a total of 70 species belonging to 40 genera and nine families distributed in different localities. Further, odonates from Madhya Pradesh are documented from Pench National Park and Satpura National Park (Ramakrishna et al., 2006), Kanha National Park (Raju \& Narayanan, 2008), Bandhavgarh Tiger Reserve (Mishra, 2009), Pachmarhi Biosphere Reserve (Prasad \& Mishra, 2009), Singhori Wildlife Sanctuary (Talmale, 2011), as well as 49 species of odonates with six new records for Madhya Pradesh from the Tropical Forest Research Institute Campus, Jabalpur (Tiple et al., 2012). Tiple (2012) recorded 70 species of odonates from Achanakmar-Amarkantak Biosphere Reserve, Madhya Pradesh and Chhattisgarh, India. Hitherto no species under the genus Burmagomphus is so far recorded from Central India (Tiple \& Chandra, 2013; Tiple et al., 2013, 2014; Tiple \& Koparde, 2015; Dawn \& Chandra, 2016). The Tropical Forest Research Institute (TFRI), Jabalpur lies on the bank of the Gour River on Varshney (1995) has shown its distribution from

*Corresponding Author:ashishdtiple@yahoo.co.in 
Mandla Road, about $10 \mathrm{~km}$ southeast of Jabalpur. The campus is spread over an area of 109 ha amidst picturesque surroundings; semi-arid with mean annual precipitation of $1358 \mathrm{~mm}$. The campus is surrounded by agricultural fields and villages. The area has trees, shrubs, grasslands and low hillocks. The water reservoir and the vegetation planted around the Institute have created a very good habitat and source of attraction for many species of insects, reptiles, birds, and mammals. Earlier, Tiple et al. (2012) reported 48 species of odonates from TFRI campus. Another specimen studied was preserved in ZSI, CZRC, collected from Singanama on the way to Matkuli to Pachmarhi lies in the Satpura hill ranges in Pachmarhi Biosphere Reserve, Hoshangabad district, Madhya Pradesh. The forest type around the locality is South Indian Moist deciduous forest with prominent teak (Tectona grandis) plantations. Singanama is a small village with agricultural area mostly growing paddy. Present study records Burmagomphus pyramidalis Laidlaw first time from Central India which was collected from Jabalpur and Pachmarhi Biosphere Reserve (Hoshangabad Dist.), Madhya Pradesh.

\section{Methodology:}

During the study of odonates from Jabalpur and vicinity, authors (AT and SP) collected a male specimen from Tropical Forest Research Institute (TFRI), on the bank of the Gour River on Mandla Road, Jabalpur, Madhya Pradesh. The specimen was collected using insect collection net. The specimen was killed by gently pressing the thorax and kept in $70 \%$ alcohol for preservation. The specimen identified as Burmagomphus pyramidalis Laidlaw (Fraser 1934). Further, author (SST) found an unidentified specimen of the same species in the National Zoological Collection of Zoological Survey of India, Central Zone Regional Centre, Jabalpur, was earlier collected from Pachmarhi Biosphere Reserve, Hoshangabad District, Madhya Pradesh in the year 2002 during the faunistic survey. Both the specimens are studied in detail and discussed here.

\section{Material Examined}

Specimen-1: 10"; Locality: Tropical Forest Research Institute, bank of the Gour River on Mandla Road, (Longitude E79 $59^{\prime} 21.87^{\prime \prime}$ \& Latitude N23이'55.86"; Altitude 412.39 meter) about $10 \mathrm{~km}$ south-east of Jabalpur, Jabalpur District, Madhya Pradesh; Date of collection:13.vii.2008. Coll. Ashish D. Tiple and Sonali V. Padwad.

Specimen 2: 10"; Locality: Singanama PWD Rest House, (Longitude E78 ${ }^{\circ} 29^{\prime} \mathrm{O} 1.72 "$ \& Latitude N22 $33^{\prime} 31.54^{\prime \prime}$; Altitude: 430.07 meters), Pachmarhi Biosphere Reserve, Hoshangabad District, Madhya Pradesh; Date of collection: 31.X.2002. Coll. Y. N. Gupta, preserved at National Zoological Collection of Zoological Survey of
India, Central Zone Regional Centre, Jabalpur-482 002, India (Reg. No.-ZSI, CZRC, A/13487).

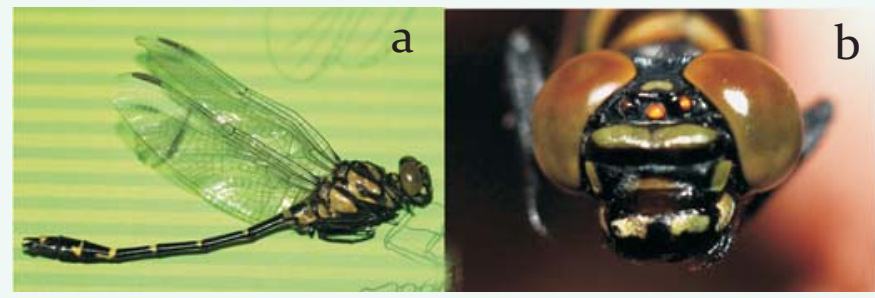

Figure-1 : a) Burmagomphus pyramidalis Laidlaw (Lateral view) collected from TFRI, Jabalpur campus; b) Head showing facial colour markings.

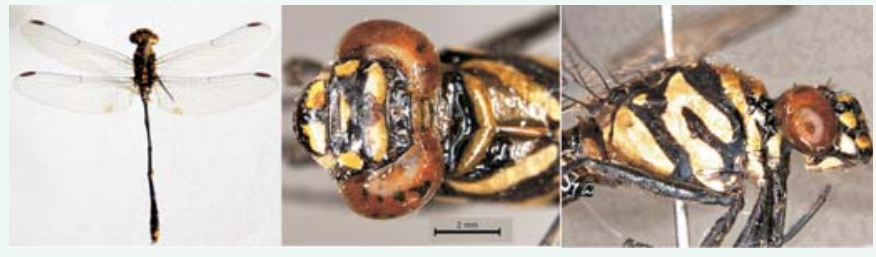

Figure-2 : a) Burmagomphus pyramidalis Laidlaw (Dorsal view) (ZSI,CZRC, A/13487) ; b) Head and thorax showing markings (Dorsal view); c) Head and thorax showing markings (Lateralview).

\section{Results and discussion:}

Burmagomphus pyramidalis Laidlaw is a shy dragonfly, very less information available about its habitat but it is certainly a riverine breeder and probably submontane in habitat choice. The adult male was curiously fond of settling on bright green foliage, where their rather cryptic sharpened markings make them very inconspicuous. We netted the specimen while settled fairly high up on a tree near the Gour river near Jabalpur. This species was not generally seen settling on rocks in mid-stream but rarely during bursts of sunshine.

Specimen-1- Measurements: Hindwing- $23 \mathrm{~mm}$; Abdomen- $30 \mathrm{~mm}$ Description (Figure-1a\&b \& Figure-3af); Head; Eyes brown above with greenish shades in the sides in wet preservation (bright brown above in life). Labium pale bluish gray, edges of lateral lobes black and a thick black stripe borders the median lobe; labrum, anteclypeus, postclypeus and frons dark greenish yellow bordered with black; bases of the mandibles black. Vertex black with greenish yellow bi-lobed spot. Prothorax black, with a distinct yellow anterior collar, also marked with citron yellow spots on each side. Thorax black marked with yellow as per Fraser (1934). The distinct large yellow median spotabove the black pyramid against the ante-alar sinuses; Complete black Y or inverted yellow Y marking present on each side of the synthorax. Legs- long, hind pair of legs extending upto anterior most part of 2nd abdominal segment but do not touch the genitalia; black, coxae marked with yellow; anterior pair of femora marked yellow on inner surface. Wings- transparent and slightly tinted with brown at bases upto anal triangle; tornus 
angulate and prominent; anal triangle 3-celled; Antenodals 13 in forewings and 9 in hindwings. Postnodals 10 in forewings and 10 in hindwings; arc situated in between first and second antenodal nurvures or parallel, close about to second; two rows of cells between IA and border of forewing. Discoidal field with two rows of cells to beyond level of node; Anal loop absent; Discoidal cell entire in all wings; Single cubital nervure in all the wings; subtrigones and hypertrigones entire; Pterostigma brown between black nervures; covers 3 cells in forewing and 4 cells in the hind; rather longer and narrower in the hind wing. Abdomen: abdomen tumid on first and second segments, then narrow and cylindrical as far as segment 7 , again expands markedly, especially at segment 8 and 9; terminal segment (10) small. Black abdomen marked with yellow as per Fraser (1934). Fringe of long backwardly directed hairs along posterior margin of inferiors. Accessory genitalia: dark brownish black, lamina depressed, broadly arched; anterior hamules short, stiletto shaped, with an inconspicuous backwardly turned point; posterior hamules very robust, more longer than broad, with a robust forwardly directed spine at apex; lobe rounded and long, shallowly grooved in front.

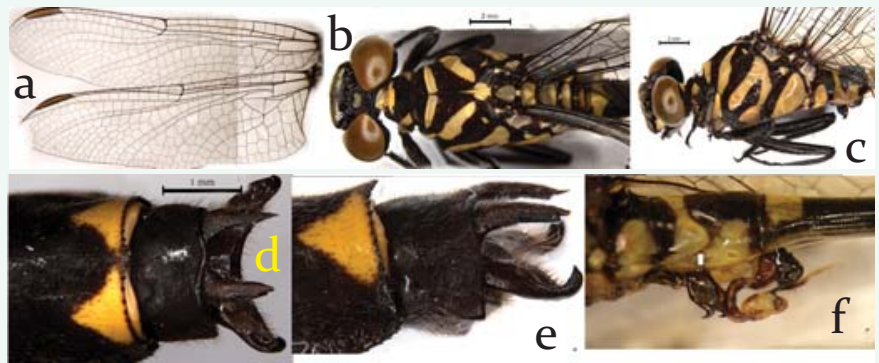

Figure-3 (Specimen-1) : a) Fore \& Hind wings (left side); b)Head \& Thorax (Dorsal view); c) Head \& Thorax (Lateral view); d) $9^{\text {th }}$ abdominal segment \& Anal appendages (Dorsal view); e) $9^{\text {th }}$ abdominal segment \& Anal appendages (Lateral view); f) Lateral view of abdominal segments showing accessorygenitalia

Specimen-2- Measurements: Hindwing- 24.5mm; Abdomen-3omm.

Description (Figure-2a-c; Figure-4a-c): Head- Eyes brown, labium pale yellowish white, middle lobe narrowly bordered with pale brown; labrum pale yellow marked with broad pale yellow spots; bases of mandibles black. Frons yellow bordered with black; Vertex black with a greenish yellow bi-lobed spot. Prothorax- black, with a fine yellow anterior colar, also marked with citron yellow spot on each side. Thorax- black marked with citron yellow; Upper antehumaral portion broad, narrow at middle, and broaden at extreme humeral portion touches to the base of 2nd pair of legs; A small upper humeral spot present representing the upper part of an obsolete humeral stripe; Distinct large yellow median spot above the black pyramid against the ante-alar sinuses; Complete black Y or inverted yellow Y marking present on each side of the synthorax. Legs- long, black, coxae marked with yellow; anterior pair of femora marked yellow on inner surface; Wings- transparent and slightly tinted with brown at bases upto anal triangle; tornus angulate and prominent; anal triangle 3-celled; Basal incomplete antenodal nervures absent in all the wings; Antenodals 12 in forewings and 9 in hindwings, Postnodals 7 in forewings and 8 in hindwings; Discoidal cell entire in all wings; Single cubital nervure in all the wings; subtrigones and hypertrigones entire; Pterostigma brown between black nervures; covers about 3 cells in forewings and 3 cell in the right hind and $3^{1 / 2}$ cells in left the hind wings; rather longer and narrower in the hind wing. Abdomen- details as per the details are given under specimen-1, except segment 9 with a conspicuous transverse citron yellow band dorsally on hind margin; studded with black denticles with central spine. Segment to entirely black. Anal appendages and accessorygenitalia-details as per Specimen-1.

\section{Variations between collected specimens and availabledescription:}

Specimen-2 is similar in most extent to the first, however, some variations observed in both the specimens, in antehumeral marking on the thorax and the 9th abdominal segment. Upper antehumeral portion narrow, broaden at middle, again somewhat narrow and broaden at extreme humeral portion touches to the base of 2nd pair of legs, also interrupted at the middle at humeral region as against upper antehumeral portion broad, narrow at middle, and broaden at extreme humeral portion in the second specimen; 9 abdominal segment with two big yellow triangular marks dorsally on hind margin in the first specimen, however, a conspicuous transverse citron yellow band dorsally on hind margin in the second specimen. The specimens under study looking close to the details given by Fraser (1926 \& 1934). However, they are variably different in labium pale bluish gray, thoracic stripes and presence of greenish yellow bi-lobed spot on vertex, a distinct large yellow median spot above the black pyramid against the ante-alar sinuses, two big yellow triangular marks dorsally on hind margin of 9th abdominal segment. It is also observed that the structural differences in accessory genitalia on the second abdominal segment in comparison with Fraser, 1926 - Fig. 3.4. The posterior hamules in the specimens more longer than broad (broad and in pyriform shape in B. pyrimidalis) and the Lobe rounded and long (round \& short in B. pyrimidalis).

Burmagomphus pyramidalis Laidlaw reported from south to southwest India, are native to Tamil Nadu, Kerala, Karnataka, and Maharashtra in the Western Ghats (Mitra, 2013). Laidlaw, (1922) recorded the species from Darjeeling, West Bengal and Tsuda (1991) recorded the same from Nepal. However, distribution of this species 
was restricted only in India by Steinmann (1997: 99) in his book "World Catalogue of Odonata". Therefore, present record of this species from Jabalpur and Pachmarhi Biosphere Reserve (Hoshangabad Dist.) in Madhya Pradesh becomes first time from the state as well as from the Central India.

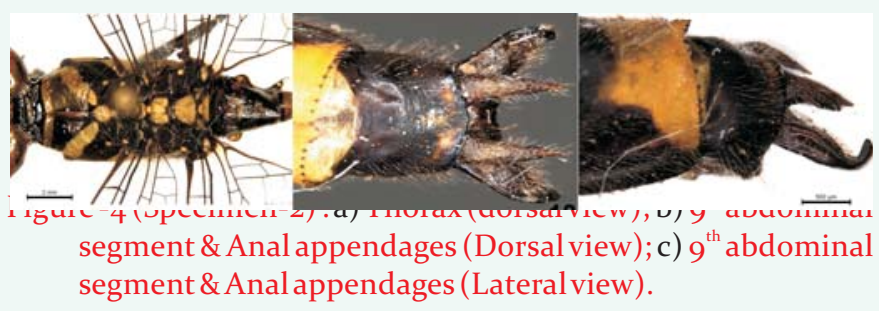

Acknowledgements:

The first author is grateful to Dr. S. Kanode, Principal, Vidyabharti College Seloo, Wardha for constant encouragement and We are grateful to Dr. Kailash Chandra, Director, Zoological Survey of India, Kolkata and Dr. S. Sambath, Off icer-in-Charge, ZSI, CZRC, Jabalpur for providing the facilities.

\section{References:}

Dawn, P. \& Chandra, K.(2016): Ten new records of Odonata from Chhattisgarh state, India (Odonata: Aeshnidae, Libellulidae, Macromiidae, Coenagrionidae, Platycnemididae). Notulae Odonatologicae, 8(7):218-221.

Fraser, F.C. (1926): Indian dragonflies, part XXIV-2. L.Bom.Nat. His. Soc., 31:408-426.

Fraser, F.C. (1934): The fauna of British India, including Ceylon and Burma: Odonata,Vol.-2; Pub. by: Taylor \& Francis, London. 1-398.

Lahiri, A.R. (1987): Studies on the Odonata fauna of Meghalaya. Rec. Zool. Surv. India, Occ.Paper, 99:1-402.

Laidlaw, F.F. (1922): A list of the dragonflies recorded from the Indian Empire with special reference to the collection of the Indian Museum. Part V. The subfamily Gomphinae. Rec. Indian Mus., 24(3):367-426.

Schorr, M. \& Paulson, D. (2016): World List of Odonata. Last revision on 27 July, 2016. Online Pub. by: University of Puget Sound, Tacoma, Washington, US.

Mishra, S.K. (2007): Insecta: Odonata In; Fauna of Madhya Pradesh (including Chhattisgarh). State Fauna Series, 15 (1): 245-272

Mishra, S.K. (2009): Insecta: Odonata. Fauna of Bandhavgarh Tiger Reserve (Madhya Pradesh). Conservation Area Series, 40:25-38.
Mitra, A. (2013): Burmagomphus pyramidalis. The IUCN Red List of Threatened Species 2013.

Mitra, T.R. (2002): Geographical Distribution of Odonata (Insecta) of Eastern India. Mem. Zool. Sur. India, 19(1):1-208.

Prasad, M. \& Varshney, R.K. (1995): A check list of the Odonata of India including data on larval studies. Orient. Insects, 29:385428.

Prasad, M. \& Mishra, S.K. (2009): Insecta: Odonata. Fauna of Pachmarhi Biosphere Reserve. Conservation Area Series, 39: 203-212.

Raju, D.V. \& Narayanan, S.P. (2008): Odonata fauna of Kanha National Park area in Central India. Fraseria, 7:5-9.

Ramakrishna, C.K., Nema, D.K., Ahirwar, S.C. \& Alfred, J.R.B. (2006): Faunal Resources of National Parks of Madhya Pradesh and Chhattisgarh. Conservation Area Series, 30:1-123

Steinmann, H. (1997): World catalogue of Odonata, Vol. II Anisoptera. Walter de Gruyter Berlin. New York, p.636.

Subramanian, K.A. (2014): A checklist of Odonata (Insecta) of India, (version 2.0.2014) Zoological Survey of India. Online Pub. by: Zoological Survey of India.

Talmale, S.S. (2011): Preliminary list of Odonata from the Singhori Wildlife Sanctuary,Madhya Pradesh. Bionotes, 13(4):159-160.

Tiple, A.D. (2012): Odonata fauna with their status of Achanakmar-Amarkantak Biosphere Reserve, Madhya Pradesh and Chhattisgarh. Inter. J. Biotech. Biosci., 2 (1):97102

Tiple, A.D., Gathalkar, G.B. \& Talmale, S.S. (2014): New record of dragongfly Ictinogomphus angulosus (Selys, 1854) from State Maharashtra, India. Ambient Sci., 1(2): 56-58.

Tiple, A.D., Paunikar, S. \& Talmale, S.S. (2012): Dragonflies and Damselflies (Odonata : Insecta) of Tropical Forest Research Institute, Jabalpur, Madhya Pradesh, Central India. Journal of Threatened Taxa, 4(4):2529-2533.

Tiple, A.D. \& Chandra, K. (2013): Dragonflies and Damselflies (Insecta, Odonata) of Madhya Pradesh and Chhattisgarh States, India. Care 4 Nature, 1(1):2-11.

Tiple, A.D. \& Koparde, P. (2015): Dragonflies and Damselflies (Insecta, Odonata) of Maharashtra States, India. L. Insect Sci., 15(1):1-10

Tsuda, S. (1991): A distributional list of World Odonata. Osaka Pref. : 1-362.

Wilson, K.D.P. (2011): Burmagomphus vermicularis. The IUCN Red List of Threatened Species 2011.

Williamson, E.B. (1907): The dragonflies (Odonata) of Burma and Lower Siam -II. Subfamilies Cordulegasterinae, Chlorogomphinae and Gomphinae. Proc. U.S. Nat. Mus., 33 267-317. 